Available online at http://jurnal.goretanpena.com/index.php/JSSR

\title{
PENERAPAN FRAMEWORK COBIT 2019 UNTUK PERANCANGAN TATA KELOLA TEKNOLOGI INFORMASI PADA PERGURUAN TINGGI
}

\author{
M Adie Saputra ${ }^{1}$, M Reza Redo ${ }^{2}$ \\ STMIK Dharmawacana Metro, Lampung \\ e-mail: adie.syaputra@Dharmawacana.ac.id
}

\begin{abstract}
The development of information technology forces universities to follow and improve resources with information technology to face competition and the times. The 2019 Cobit Framework is one of the guidelines that can be used to apply Information Technology for Information Technology governance at Business Technology Institutions and Dinniyah Lampung because it can assist the management of Information Technology management frameworks. information technology in business and technology management so that information is obtained related to existing governance.
\end{abstract}

Keywords: Cobit 2019, Governance, College.

\begin{abstract}
Abstrak: Berkembangnya teknologi informasi memaksa perguruan tinggi untuk dapat mengikuti dan meningkatkan sumber daya dengan teknologi informasi untuk menghadapi persaingan dan perkembangan zaman. Framework Cobit 2019 menjadi salah satu panduan yang dapat digunakan untuk menerapkan Teknologi Informasi untuk tata kelola Teknologi Informasi pada Institusi Teknologi Bisnis dan Dinniyah Lampung karena dapat memberikan masukan dalam membantu pengelolaan kerangka keja manajemen Teknologi Informasi Penelitian ini bertujuan menerapkan Framework Cobit 2019 untuk membangun rancangan tata kelola teknologi informasi dalam pengelolaan bisnis dan teknologi sehingga didapatkan informasi berhubungan dengan tatakelola yang telah berjalan.
\end{abstract}

Kata kunci: Cobit 2019, Tata Kelola, Perguruan Tinggi.

\section{PENDAHULUAN}

Dengan teknologi informasi diharapkan dapat memberikan manfaat bagi stakeholder baik dalam pengambilan keputusan, kebutuhan sumber daya manusia, ataupun untuk perubahan model bisnis Perguruan Tinggi Institusi Teknologi Bisnis dan Diniyyah Lampung (Instidla) sebagai perguruan tinggi yang memanfaatkan teknologi informasi masih memilki permasalahan terutama dalam mengoptimalkan kinerja para sumber daya manusia. Sumber daya manusia bidang Teknologi Informasi yang dimilki berjumlah 4 orang, di mana sumber daya tersebut yang membantu permasalahan yang ada pada Instidla serta 3 program studi yang ada saat ini sehingga hal ini yang menyebabkan tertundanya penyelesaian pekerjaan dalam mengelola
Teknologi Informasi pada Instidla, permasalahan berikutnya pada human error saat menginputkan data sehingga terjadi kurangnya singkronisasi data/informasi sehingga jika ada 1 kesalahan maka akan merunut pada bagian lainnya, permasalahan selanjutnya pada penggunaan website, di mana diperlukan perkembangan informasi/ data sehingga mampu memenuhi kebutuhan para stakeholder. Framework Cobit 2019 menjadi panduan yang dapat digunakan untuk menerapkan Teknologi Informasi untuk tata kelola Teknologi Informasi pada Institusi Teknologi Bisnis dan Dinniyah Lampung karena dapat memberikan masukan dalam membantu pengelolaan kerangka keja manajemen Teknologi Informasi. Penelitian ini bertujuan menerapkan Framework Cobit 2019 untuk membangun rancangan tata 
Available online at http://jurnal.goretanpena.com/index.php/JSSR

kelola teknologi informasi dalam pengelolaan bisnis dan teknologi. Selain itu beberapa penelitian sebelumnya framework cobit juga dapat menyelesaikan masalah diantaranya terkait tentang Manajement Blok Bangunan dan Peluang Penelitian(De Haes, Van Grembergen, and Debreceny 2013), Manajement Pelaporan Pajak(Gunadi and Widianto 2020), Tentang tata kelola pemerintahan(Abdulrasool and Turnbull 2020; Evangelista et al. 2020; Fantini, Pinzone, and Taisch 2020; De Haes et al. 2020, 2013; Haouam 2020; Majumdar, Garg, and Jain 2021; Nachrowi, Nurhadryani, and Sukoco 2020; Syuhada 2021) sehingga atas dasar penelitian penelitian sebelumnya framework cobit ini menjadi panduan untuk menerapkan tata kelola teknologi informasi.

\section{METODE}

Pengumpulan Data dan Sampel Metode yang digunakan dalam melakukan pembuatan sistem ini adalah menganalisa hubungan keadaan data dan melakukan pengumpulan data dengan metode:

Wawancara

Pengumpulan data melalui wawancara dilakukan dalam suasana tidak formal. Penulis melakukan wawancara terhadap Wakil Raktor serta bagian akademik, bagian kemahasiswaan dan lppm, Wakil Rektor 2 serta bagian umum, bagian kepegawaian dan bagian logistik, ketua-ketua program studi. Pertanyaannya pun hanya untuk mengetahui job desk, prosedur serta kendala yang sering terjadi.

\section{Studi Literatur}

Proses yang dilakukan dengan cara mencari dasar teori dan penemuan dari penelitian yang telah diakukan sebelumnya. Teori-teori yang memiliki permasalahan penelitian COBIT 2019 dan penelitian yang menggunakan framework COBIT versi lainnya berusaha digali dan dirangkumkan secara singkat sesuai dengan kebutuhan dalam penelitian ini. Studi literatur dilakukan dengan membaca, merangkum, kemudian menuliskannya kembali dengan metode yang sudah ditentukan. Teori diperoleh dari website resmi ISACA serta jurnaljurnal.

\section{Kuisioner Sampel}

Kuisioner dalam penelitian ini dirancang untuk mengetahui tingkat kematangan pengelolaan teknologi informasi yang telah digunakan dengan melihat tanggapan pengguna dan pembuatan keputusan dalam mennggunakan teknologi. Penyebaran kuisioner akan dilakukan sesuai dengan tabel responden, dengan melibatkan SDM terkait dengan penggunaan dan pengelolaan teknologi informasi. Kuisoner akan berisi pertanyaanpertanyaan sesuai pada domain APO07 (Manage Human Resources), Masingmasing penilaian memiliki tingkat nilai yang berbobot antara 0 sampai dengan 5 sesuai dengan dasar yang terdapat pada model COBIT 2019.

Penerapan Framework COBIT 2019 Dalam penerapannya tahapan yang berdasarkan pada kerangka kerja COBIT 2019, yaitu :

Initiate Programme yaitu menjelaskan tentang penggerak pada organisasi. Idnetifikasi penggerak perubahan saat ini dan kebutuhan perubahan pada tingkat manjemen eksekutif. Tujuannnya adalah memperoleh pemahaman tentang organisasi saat ini.

Define Problems and Opportunities yaitu menjelaskan tentang kemampuan organisasi saat ini, kekurangan yang dimiliki dan semua yang berhubungan dengan teknologi informasi.

Define Road Map dengan menerapkan target untuk perbaikan yang diikuti dengan analisa gap untuk mengidentifikasi potensi solusi,

Plan Programme untuk menjelaskan tentang rencana dan solusi praktis untuk organisasi dengan mendefinisikan rekomendasi perbaikan perubahan rencana pengembangan 
Available online at http://jurnal.goretanpena.com/index.php/JSSR

\section{HASIL DAN PEMBAHASAN}

Define Problems and Opportunities (Idnetifikasi Proses Teknologi Informasi) Adapun susunan menurut domain yang akan digunakan pada Instidla adalah ditunjukkan pada Tabel.

Tabel 1. Proses Teknologi Informasi pada

\begin{tabular}{ll}
\multicolumn{2}{c}{ Insitdla } \\
\hline IT Domain & IT Process \\
& \\
Align, & $A P O-$ \\
Plan, and & $O 7$ Manage \\
\hline
\end{tabular}

Sedangkan Deskripsi tiap-tiap proses teknologi informasi di atas dipaparkan pada Tabel 2

Tabel 2. Daftar Proses Teknologi pada Instidla

\begin{tabular}{|l|l|}
\hline $\begin{array}{l}\text { Domain } \\
\text { Proses }\end{array}$ & Deskripsi Proses \\
\hline APO07 & $\begin{array}{l}\text { Pengelolaan } \\
\text { Sumber Daya }\end{array}$ \\
\hline
\end{tabular}

Menentukan Tingkat Kematangan Penentuan tingkat kemampuan saat ini dilakukaan melalui kuisioner yang diberikan kepada responden yang telah ditentukan sebelumnya.

Berdasarkan rekapitulasi jawaban dari para responden (terlampir), maka didapatkan nilai tingkat kapabilitas saat ini pada rentang 0-5. Nilai capability tertinggi terdapat pada APO07

Indikator Tabel:

$\mathrm{P}$ : Proses

L : Level

Q : Pertanyaan

A : Jawaban

$\mathrm{K}$ : Konversi

rK: Rerata Konversi

$\mathrm{N}$ : Normalisasi

NL: Normalisasi Level

Tabel 3. Daftar hasil pengolahan kuisioner APO07.01 (Memperoleh dan Memelihara Staff)

\begin{tabular}{|c|c|c|c|c|c|c|c|}
\hline $\mathbf{P}$ & $\mathbf{L}$ & $\mathbf{Q}$ & $\mathbf{A}$ & $\mathbf{K}$ & rK & $\mathbf{N}$ & NL \\
\hline \multirow{30}{*}{$\begin{array}{l}\overline{8} \\
\hat{8} \\
\hat{8}\end{array}$} & \multirow[t]{6}{*}{1} & $\mathrm{P}$ & $\mathrm{Ya}$ & 1 & 0,3 & \multirow{6}{*}{$\begin{array}{c}0,3 \\
3\end{array}$} & \multirow{6}{*}{$\begin{array}{c}0,3 \\
3\end{array}$} \\
\hline & & 1 & & & 3 & & \\
\hline & & $\mathrm{P}$ & Ya & 1 & 0,3 & & \\
\hline & & 2 & & & 3 & & \\
\hline & & $\mathrm{P}$ & Ya & 1 & 0,3 & & \\
\hline & & 3 & & & 3 & & \\
\hline & \multirow[t]{6}{*}{2} & $P$ & Ya & 1 & 0,3 & \multirow{6}{*}{$\begin{array}{c}0,3 \\
3\end{array}$} & \multirow{6}{*}{$\begin{array}{c}0,6 \\
7\end{array}$} \\
\hline & & 1 & & & 3 & & \\
\hline & & $P$ & $\mathrm{Ya}$ & 1 & 0,3 & & \\
\hline & & 2 & & & 3 & & \\
\hline & & $\mathrm{P}$ & Ya & 1 & 0,3 & & \\
\hline & & 3 & & & 3 & & \\
\hline & \multirow[t]{6}{*}{3} & $P$ & $\mathrm{Ya}$ & 1 & 0,3 & \multirow{6}{*}{$\begin{array}{c}0,3 \\
3\end{array}$} & \multirow{6}{*}{$\begin{array}{c}1,0 \\
0\end{array}$} \\
\hline & & 1 & & & 3 & & \\
\hline & & $\mathrm{P}$ & Ya & 1 & 0,3 & & \\
\hline & & 2 & & & 3 & & \\
\hline & & $\mathrm{P}$ & Ya & 1 & 0,3 & & \\
\hline & & 3 & & & 3 & & \\
\hline & \multirow[t]{6}{*}{4} & $\mathrm{P}$ & Tida & 0 & 0,0 & & \\
\hline & & 1 & $\mathrm{k}$ & & 0 & & \\
\hline & & $P$ & Tida & 0 & 0,0 & & \\
\hline & & 2 & $\mathrm{k}$ & & 0 & & \\
\hline & & $P$ & Tida & 0 & 0,0 & & \\
\hline & & 3 & $\mathrm{k}$ & & 0 & & \\
\hline & \multirow[t]{7}{*}{5} & $\mathrm{P}$ & Tida & 0 & 0,0 & & \\
\hline & & 1 & $\mathrm{k}$ & & 0 & & \\
\hline & & $P$ & Tida & 0 & 0,0 & & \\
\hline & & 2 & $\mathrm{k}$ & & 0 & & \\
\hline & & $\mathrm{P}$ & Tida & 0 & 0,0 & & \\
\hline & & 3 & $\mathrm{k}$ & & 0 & & \\
\hline & & & & & & & $\begin{array}{c}2,0 \\
0\end{array}$ \\
\hline
\end{tabular}

Normalisasi Level 1

$\mathrm{N}=\frac{\sum R K i}{\sum R K a}$

$\mathrm{N}=\frac{0,33+0,33+0,33}{2,97}$

$\mathrm{N}=0,33$

Normalisasi Level 2

$\mathrm{N}=\frac{\sum R K i}{\sum R K a}$

$\mathrm{N}=\frac{0,33+0,33+0,33}{2,97}$

$\mathrm{N}=0,33$

Normalisasi Level 3

$\mathrm{N}=\frac{\sum R K i}{\sum R K a}$

$\mathrm{N}=\frac{0,33+0,33+0,33}{2,97}$

$\mathrm{N}=0,33$ 
Available online at http://jurnal.goretanpena.com/index.php/JSSR

\section{Normalisasi Level 4, 5}

$$
\begin{aligned}
& \mathrm{N}=\frac{\sum R K i}{\sum R K a} \\
& \mathrm{~N}=\frac{0+0+0}{2,97} \\
& \mathrm{~N}=0,00
\end{aligned}
$$

Tabel 4. Daftar hasil pengolahan

\begin{tabular}{|c|c|c|c|c|c|c|c|}
\hline $\mathbf{P}$ & $\mathbf{L}$ & $\mathbf{Q}$ & $\mathbf{A}$ & K & $\begin{array}{l}\mathbf{r} \\
\mathbf{K}\end{array}$ & $\mathbf{N}$ & NL \\
\hline \multirow{38}{*}{ 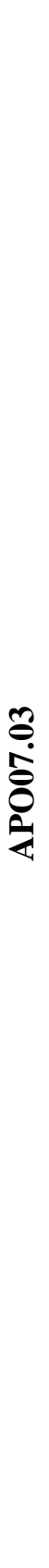 } & \multirow[t]{10}{*}{1} & $\mathrm{P}$ & $\mathrm{Ya}$ & 1 & 0 , & \multirow{10}{*}{$\begin{array}{l}0,3 \\
3\end{array}$} & \multirow{10}{*}{$\begin{array}{l}0,3 \\
3\end{array}$} \\
\hline & & 1 & & & 2 & & \\
\hline & & $\mathrm{P}$ & $\mathrm{Ya}$ & 1 & 0 , & & \\
\hline & & 2 & & & 2 & & \\
\hline & & $\mathrm{P}$ & $\mathrm{Ya}$ & 1 & 0 , & & \\
\hline & & 3 & & & 2 & & \\
\hline & & $\mathrm{P}$ & Tida & 0 & 0 & & \\
\hline & & 4 & k & & & & \\
\hline & & $P$ & Tida & 0 & 0 & & \\
\hline & & 5 & $\mathrm{k}$ & & & & \\
\hline & \multirow[t]{10}{*}{2} & $\mathrm{P}$ & $\mathrm{Ya}$ & 1 & 0 & \multirow{10}{*}{$\begin{array}{l}0,3 \\
3\end{array}$} & \multirow{10}{*}{$\begin{array}{l}0,6 \\
7\end{array}$} \\
\hline & & 1 & & & 2 & & \\
\hline & & $\mathrm{P}$ & Ya & 1 & 0 & & \\
\hline & & 2 & & & 2 & & \\
\hline & & $\mathrm{P}$ & Ya & 1 & 0 , & & \\
\hline & & 3 & & & 2 & & \\
\hline & & $\mathrm{P}$ & Tida & 0 & 0 & & \\
\hline & & 4 & k & & & & \\
\hline & & $\mathrm{P}$ & Tida & 0 & 0 & & \\
\hline & & 5 & k & & & & \\
\hline & 3 & $\mathrm{P}$ & Ya & 1 & 0 & \multirow{10}{*}{$\begin{array}{l}0,3 \\
3\end{array}$} & \multirow{10}{*}{$\begin{array}{l}1,0 \\
0\end{array}$} \\
\hline & & 1 & & & 2 & & \\
\hline & & $\mathrm{P}$ & Ya & 1 & 0 & & \\
\hline & & 2 & & & 2 & & \\
\hline & & $\mathrm{P}$ & $\mathrm{Ya}$ & 1 & 0 & & \\
\hline & & 3 & & & 2 & & \\
\hline & & $\mathrm{P}$ & Tida & 0 & 0 & & \\
\hline & & 4 & k & & & & \\
\hline & & $\mathrm{P}$ & Tida & 0 & 0 & & \\
\hline & & 5 & k & & & & \\
\hline & \multirow[t]{8}{*}{4} & $\mathrm{P}$ & Tida & 0 & 0 & & \\
\hline & & 1 & k & & & & \\
\hline & & $\mathrm{P}$ & Tida & 0 & 0 & & \\
\hline & & 2 & k & & & & \\
\hline & & $\mathrm{P}$ & Tida & 0 & 0 & & \\
\hline & & 3 & k & & & & \\
\hline & & $P$ & Tida & 0 & 0 & & \\
\hline & & 4 & $\mathrm{k}$ & & & & \\
\hline
\end{tabular}
kuisioner APO07.03 (Keterampilan dan Kompetensi Staff)

\begin{tabular}{llllll}
\hline & $\mathrm{P}$ & Tida & 0 & 0 & \\
& 5 & $\mathrm{k}$ & & & \\
\hline 5 & $\mathrm{P}$ & Tida & 0 & 0 & \\
& 1 & $\mathrm{k}$ & & & \\
& $\mathrm{P}$ & Tida & 0 & 0 & \\
2 & $\mathrm{k}$ & & & \\
& $\mathrm{P}$ & Tida & 0 & 0 & \\
3 & $\mathrm{k}$ & & & \\
\hline $\mathrm{P}$ & Tida & 0 & 0 & \\
4 & $\mathrm{k}$ & & & \\
\hline $\mathrm{P}$ & Tida & 0 & 0 & \\
5 & $\mathrm{k}$ & & & \\
\hline & & & & & 2,0 \\
& & & & \\
\hline
\end{tabular}

Normalisasi Level 1

$\mathrm{N}=\frac{\sum R K i}{\sum R K a}$

$\mathrm{N}=\frac{0,2+0,2+0,2+0+0}{1,8}$

$\mathrm{N}=0,33$

Normalisasi Level 2

$\mathrm{N}=\frac{\sum R K i}{\sum R K a}$

$\mathrm{N}=\frac{0,2+0,2+0,2+0+0}{1,8}$

$\mathrm{N}=0,33$

Normalisasi Level 3

$\mathrm{N}=\frac{\sum R K i}{\sum R K a}$

$\mathrm{N}=\frac{0,2+0,2+0,2+0+0}{1,8}$

$\mathrm{N}=0,33$

Normalisasi Level 4, 5

$\mathrm{N}=\frac{\sum R K i}{\sum R K a}$

$\mathrm{N}=\frac{\mathrm{0+0+0}}{3,00}$

$\mathrm{N}=0,00$

\begin{tabular}{|c|c|c|c|c|c|c|c|}
\hline $\mathbf{P}$ & $\mathbf{L}$ & $\mathbf{Q}$ & $\mathbf{A}$ & $\mathbf{K}$ & $\begin{array}{l}\mathbf{r} \\
\mathbf{K}\end{array}$ & $\mathbf{N}$ & NL \\
\hline \multirow{6}{*}{ 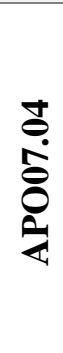 } & \multirow[t]{6}{*}{1} & $\mathrm{P}$ & $\mathrm{Ya}$ & 1 & 0 & \multirow{6}{*}{$\begin{array}{l}0,3 \\
6\end{array}$} & 0,3 \\
\hline & & 1 & & & 2 & & 6 \\
\hline & & P & $\mathrm{Ya}$ & 1 & 0 , & & \\
\hline & & $\mathrm{P}$ & $\mathrm{Ya}$ & 1 & 0 & & \\
\hline & & 3 & & & 2 & & \\
\hline & & $\mathrm{P}$ & $\mathrm{Ya}$ & 1 & 0 , & & \\
\hline
\end{tabular}

Tabel 5. Daftar hasil pengolahan kuisioner APO07.04 (Kinerja Karyawan) 
Available online at http://jurnal.goretanpena.com/index.php/JSSR

\begin{tabular}{|c|c|c|c|c|c|c|}
\hline \multirow[t]{7}{*}{2} & $\begin{array}{l}\mathrm{P} \\
1\end{array}$ & $\mathrm{Ya}$ & 1 & $\begin{array}{l}0, \\
2\end{array}$ & \multirow[t]{7}{*}{$\begin{array}{l}0,3 \\
6\end{array}$} & \multirow[t]{7}{*}{$\begin{array}{l}0,7 \\
3\end{array}$} \\
\hline & $\mathrm{P}$ & $\mathrm{Ya}$ & 1 & 0 & & \\
\hline & 2 & & & 2 & & \\
\hline & $\mathrm{P}$ & Ya & 1 & 0 & & \\
\hline & 3 & & & 2 & & \\
\hline & $\mathrm{P}$ & Ya & 1 & 0 & & \\
\hline & 4 & & & 2 & & \\
\hline \multirow[t]{8}{*}{3} & $\mathrm{P}$ & Ya & 1 & 0 & \multirow{8}{*}{$\begin{array}{l}0,2 \\
7\end{array}$} & \multirow{8}{*}{$\begin{array}{l}0,8 \\
2\end{array}$} \\
\hline & 1 & & & 2 & & \\
\hline & $\mathrm{P}$ & $\mathrm{Ya}$ & 1 & 0 & & \\
\hline & 2 & & & 2 & & \\
\hline & $\mathrm{P}$ & Tida & 0 & 0 & & \\
\hline & 3 & $\mathrm{k}$ & & & & \\
\hline & $\mathrm{P}$ & $\mathrm{Ya}$ & 1 & 0 & & \\
\hline & 4 & & & 2 & & \\
\hline \multirow[t]{8}{*}{4} & $P$ & Tida & 0 & 0 & & \\
\hline & 1 & $\mathrm{k}$ & & & & \\
\hline & $\mathrm{P}$ & Tida & 0 & 0 & & \\
\hline & 2 & $\mathrm{k}$ & & & & \\
\hline & $\mathrm{P}$ & Tida & 0 & 0 & & \\
\hline & 3 & $\mathrm{k}$ & & & & \\
\hline & $P$ & Tida & 0 & 0 & & \\
\hline & 4 & $\mathrm{k}$ & & & & \\
\hline \multirow[t]{9}{*}{5} & $\mathrm{P}$ & Tida & 0 & 0 & & \\
\hline & 1 & $\mathrm{k}$ & & & & \\
\hline & $\mathrm{P}$ & Tida & 0 & 0 & & \\
\hline & 2 & k & & & & \\
\hline & $\mathrm{P}$ & Tida & 0 & 0 & & \\
\hline & 3 & $\mathrm{k}$ & & & & \\
\hline & $\mathrm{P}$ & Tida & 0 & 0 & & \\
\hline & 4 & k & & & & \\
\hline & & & & & & $\begin{array}{l}1,9 \\
1\end{array}$ \\
\hline
\end{tabular}

$\mathrm{N}=0,27$

Normalisasi Level 4, 5

$$
\begin{aligned}
& \mathrm{N}=\frac{\sum R K i}{\sum_{R K a}} \\
& \mathrm{~N}=\frac{0+0+0}{3,00} \\
& \mathrm{~N}=0,00
\end{aligned}
$$

Tabel 6. Daftar hasil pengolahan

\begin{tabular}{|c|c|c|c|c|c|c|c|}
\hline $\mathbf{P}$ & $\mathbf{L}$ & $\mathbf{Q}$ & $\mathbf{A}$ & K & $\begin{array}{l}\mathbf{r} \\
\mathbf{K}\end{array}$ & $\mathbf{N}$ & NL \\
\hline \multirow{30}{*}{ 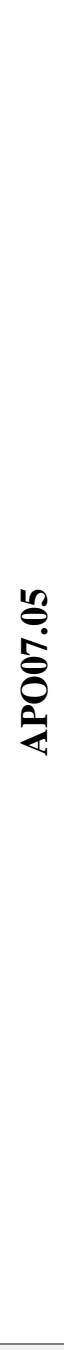 } & \multirow[t]{6}{*}{1} & $\mathrm{P}$ & Tida & 0 & 0 & \multirow{6}{*}{$\begin{array}{l}0,2 \\
9\end{array}$} & \multirow{6}{*}{$\begin{array}{l}0,2 \\
9\end{array}$} \\
\hline & & 1 & $\mathrm{k}$ & & & & \\
\hline & & $\mathrm{P}$ & $\mathrm{Ya}$ & 1 & 0 & & \\
\hline & & 2 & & & 2 & & \\
\hline & & $\mathrm{P}$ & Ya & 1 & 0 & & \\
\hline & & 3 & & & 2 & & \\
\hline & \multirow[t]{6}{*}{2} & $\mathrm{P}$ & $\mathrm{Ya}$ & 1 & 0 & \multirow{6}{*}{$\begin{array}{l}0,4 \\
3\end{array}$} & \multirow{6}{*}{$\begin{array}{l}0,8 \\
6\end{array}$} \\
\hline & & 1 & & & 2 & & \\
\hline & & $\mathrm{P}$ & $\mathrm{Ya}$ & 1 & 0 & & \\
\hline & & 2 & & & 2 & & \\
\hline & & $\mathrm{P}$ & $\mathrm{Ya}$ & 1 & 0 , & & \\
\hline & & 3 & & & 2 & & \\
\hline & \multirow[t]{6}{*}{3} & $P$ & $\mathrm{Ya}$ & 1 & 0 & \multirow{6}{*}{$\begin{array}{l}0,2 \\
9\end{array}$} & \multirow{6}{*}{$\begin{array}{l}0,8 \\
6\end{array}$} \\
\hline & & 1 & & & 2 & & \\
\hline & & $\mathrm{P}$ & $\mathrm{Ya}$ & 1 & 0 , & & \\
\hline & & 2 & & & 2 & & \\
\hline & & $\mathrm{P}$ & Tida & 0 & 0 & & \\
\hline & & 3 & $\mathrm{k}$ & & & & \\
\hline & \multirow[t]{6}{*}{4} & $\mathrm{P}$ & Tida & 0 & 0 & \multirow[t]{6}{*}{0} & \multirow[t]{6}{*}{0} \\
\hline & & 1 & $\mathrm{k}$ & & & & \\
\hline & & $P$ & Tida & 0 & 0 & & \\
\hline & & 2 & $\mathrm{k}$ & & & & \\
\hline & & $P$ & Tida & 0 & 0 & & \\
\hline & & 3 & $\mathrm{k}$ & & & & \\
\hline & \multirow[t]{8}{*}{5} & $\mathrm{P}$ & Tida & 0 & 0 & \multirow[t]{8}{*}{0} & \multirow[t]{6}{*}{0} \\
\hline & & 1 & $\mathrm{k}$ & & & & \\
\hline & & $\mathrm{P}$ & Tida & 0 & 0 & & \\
\hline & & 2 & $\mathrm{k}$ & & & & \\
\hline & & $\mathrm{P}$ & Tida & 0 & 0 & & \\
\hline & & 3 & $\mathrm{k}$ & & & & \\
\hline & & & & & & & 2,0 \\
\hline & & & & & & & 1 \\
\hline
\end{tabular}
kuisioner APO07.05 (Perencanaan, Pelacakan dan Tanggung Jawab I\&T)

Normalisasi Level 1

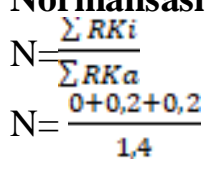


Available online at http://jurnal.goretanpena.com/index.php/JSSR

$\mathrm{N}=0,29$

\section{Normalisasi Level 2}

$$
\begin{aligned}
& \mathrm{N}=\frac{\sum R K i}{\sum R K a} \\
& \mathrm{~N}=\frac{0,2+0,2+0,2}{1,4} \\
& \mathrm{~N}=0,43
\end{aligned}
$$

Normalisasi Level 3

$$
\begin{aligned}
& \mathrm{N}=\frac{\sum R K i}{\sum R K a} \\
& \mathrm{~N}=\frac{0,2+0,2}{1,4} \\
& \mathrm{~N}=0,29
\end{aligned}
$$

\begin{tabular}{|c|c|c|c|c|c|c|c|}
\hline $\mathbf{P}$ & $\mathbf{L}$ & $\mathbf{Q}$ & $\mathbf{A}$ & $\mathbf{K}$ & $\begin{array}{l}\mathbf{r} \\
\mathbf{K}\end{array}$ & $\mathbf{N}$ & NL \\
\hline \multirow{27}{*}{ 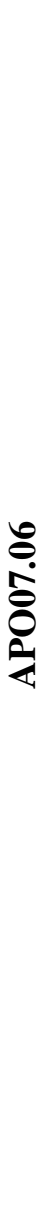 } & \multirow[t]{8}{*}{1} & $\mathrm{P}$ & $\mathrm{Ya}$ & 1 & 0 , & 0,3 & 0,3 \\
\hline & & 1 & & & 2 & \multirow[t]{7}{*}{3} & \multirow[t]{7}{*}{3} \\
\hline & & $\mathrm{P}$ & $\mathrm{Ya}$ & 1 & 0 , & & \\
\hline & & 2 & & & 2 & & \\
\hline & & $\mathrm{P}$ & $\mathrm{Ya}$ & 1 & 0 , & & \\
\hline & & 3 & & & 2 & & \\
\hline & & $\mathrm{P}$ & $\mathrm{Ya}$ & 1 & 0 , & & \\
\hline & & 4 & & & 2 & & \\
\hline & \multirow[t]{8}{*}{2} & $\mathrm{P}$ & $\mathrm{Ya}$ & 1 & 0 , & \multirow{8}{*}{$\begin{array}{l}0,3 \\
3\end{array}$} & \multirow{8}{*}{$\begin{array}{l}0,6 \\
7\end{array}$} \\
\hline & & 1 & & & 2 & & \\
\hline & & $\mathrm{P}$ & $\mathrm{Ya}$ & 1 & 0 , & & \\
\hline & & 2 & & & 2 & & \\
\hline & & $\mathrm{P}$ & $\mathrm{Ya}$ & 1 & 0 , & & \\
\hline & & 3 & & & 2 & & \\
\hline & & $\mathrm{P}$ & $\mathrm{Ya}$ & 1 & 0 & & \\
\hline & & 4 & & & 2 & & \\
\hline & \multirow[t]{8}{*}{3} & $\mathrm{P}$ & $\mathrm{Ya}$ & 1 & 0 , & \multirow{8}{*}{$\begin{array}{l}0,3 \\
3\end{array}$} & \multirow{8}{*}{$\begin{array}{l}1,0 \\
0\end{array}$} \\
\hline & & 1 & & & 2 & & \\
\hline & & $\mathrm{P}$ & $\mathrm{Ya}$ & 1 & 0 , & & \\
\hline & & 2 & & & 2 & & \\
\hline & & $\mathrm{P}$ & $\mathrm{Ya}$ & 1 & 0 , & & \\
\hline & & 3 & & & 2 & & \\
\hline & & $\mathrm{P}$ & $\mathrm{Ya}$ & 1 & 0 , & & \\
\hline & & 4 & & & 2 & & \\
\hline & \multirow[t]{3}{*}{4} & $\mathrm{P}$ & Tida & 0 & 0 & & \\
\hline & & 1 & $\mathrm{k}$ & & & & \\
\hline & & $\mathrm{P}$ & Tida & 0 & 0 & & \\
\hline
\end{tabular}

Normalisasi Level 4, 5

$$
\begin{aligned}
& \mathrm{N}=\frac{\sum R K i}{\sum_{R K a}} \\
& \mathrm{~N}=\frac{0+0+0}{3,00} \\
& \mathrm{~N}=0,00
\end{aligned}
$$

Tabel 7. Daftar hasil pengolahan kuisioner APO07.06 (Pengelolaan Staff)

\begin{tabular}{lllll}
\hline & 2 & $\mathrm{k}$ & & \\
\cline { 2 - 4 } & $\mathrm{P}$ & Tida & 0 & 0 \\
3 & $\mathrm{k}$ & & \\
\hline & $\mathrm{P}$ & Tida & 0 & 0 \\
4 & $\mathrm{k}$ & & \\
\hline 5 & $\mathrm{P}$ & Tida & 0 & 0 \\
& 1 & $\mathrm{k}$ & & \\
\hline & $\mathrm{P}$ & Tida & 0 & 0 \\
2 & $\mathrm{k}$ & & \\
\hline $\mathrm{P}$ & $\mathrm{Tida}$ & 0 & 0 & \\
3 & $\mathrm{k}$ & & \\
\hline $\mathrm{P}$ & Tida & 0 & 0 & \\
4 & $\mathrm{k}$ & & & \\
& & & & \\
& & & \\
\end{tabular}

\section{Normalisasi Level 1}

$\mathrm{N}=\frac{\sum R K i}{\sum R K a}$

$\mathrm{N}=\frac{0,2+0,2+0,2+0,2}{2,4}$

$\mathrm{N}=0,33$

Normalisasi Level 2

$\mathrm{N}=\frac{\sum R K i}{\sum R K a}$

$\mathrm{N}=\frac{0,2+0,2+0,2+0.2}{2,4}$

$\mathrm{N}=0,33$

Normalisasi Level 3

$\mathrm{N}=\frac{\sum R K i}{\sum R K a}$

$\mathrm{N}=\frac{0,2+0,2+0,2+0,2}{2,4}$

$\mathrm{N}=0,27$

Normalisasi Level 4, 5

$\mathrm{N}=\frac{\sum R K i}{\sum R K a}$

$\mathrm{N}=\frac{0+0+0}{3,00}$

$\mathrm{N}=0,00$

Berdasarkan hasil pengolahan data kuisioner di atas dpat digambarkan :

1. Normalisasi level pada proses memeproleh dan memelihara staff/karyawan (APO07.01) adalah 2,00

2. Normalisasi level pada proses identifikasi personal I\&T (APO07.02) adalah 2,00

3. Normalisasi level pada proses keterampilan dan kompetensi staff/karyawan (APO07.03) adalah 
Available online at http://jurnal.goretanpena.com/index.php/JSSR

\section{2,00}

4. Normalisasi level pada proses kinerja karyawan (APO07.04) adalah 1,91

5. Normalisasi level pada proses perencanaan, pelacakan dan tanggung jawab I\&T (APO07.05) adalah 2,01

6. Normalisasi level pada proses pengelolaan staff/karyawan (APO07.06) adalah 2,00

Perhitungan Capability Level Manage Human Resource (APO07)

Indikator Tabel:

$P$ : Proses

$\mathrm{R}$ : Responden

L : Level

CL : Capability Level

Tabel 8. Daftar Hasil Perhitungan Capability Level APO07.01 (Memperoleh dan memeilihara Staff)

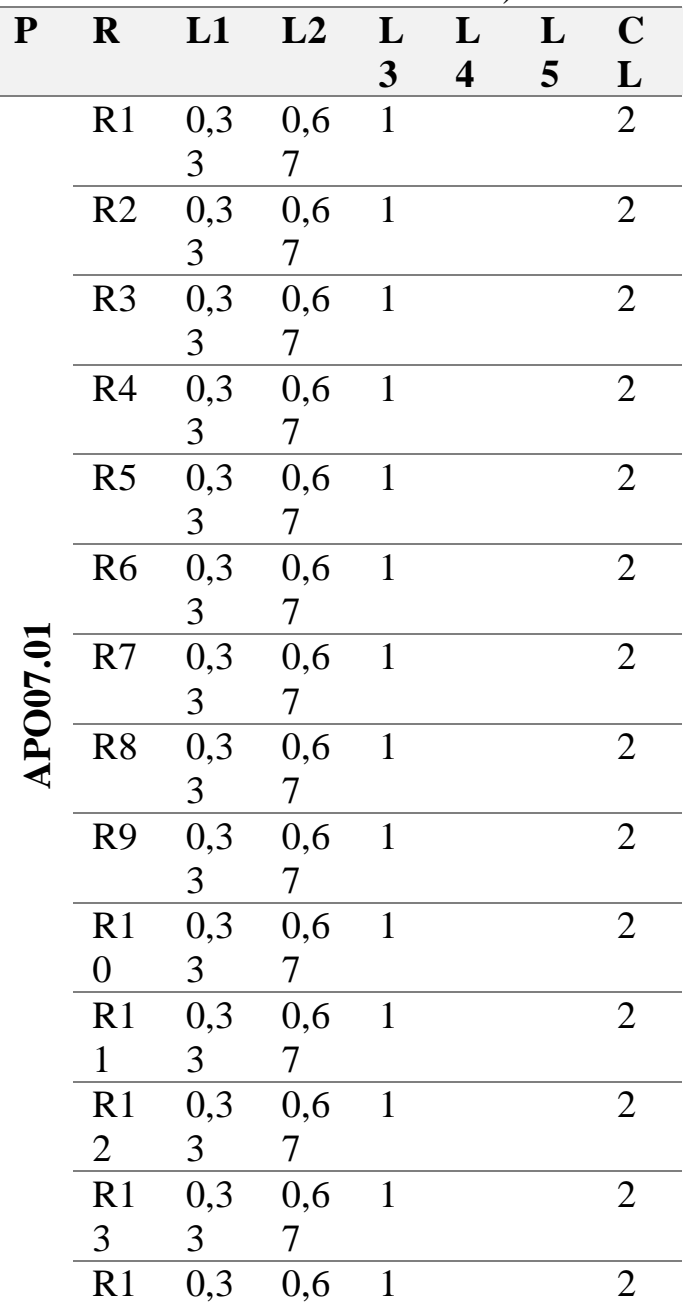

\begin{tabular}{lllll}
4 & 3 & 7 & & \\
\hline R1 & 0,3 & 0,6 & 1 & 2 \\
5 & 3 & 7 & & \\
\hline
\end{tabular}

Tabel 9. Daftar Hasil Perhitungan Capability Level APO07.02 (Identifikasi Personal IT)

\begin{tabular}{|c|c|c|c|c|c|c|c|}
\hline $\mathbf{P}$ & $\mathbf{R}$ & L1 & L2 & $\begin{array}{l}\mathbf{L} \\
\mathbf{3}\end{array}$ & $\begin{array}{l}L \\
4\end{array}$ & $\begin{array}{l}\mathbf{L} \\
5\end{array}$ & $\begin{array}{l}\mathbf{C} \\
\mathbf{L}\end{array}$ \\
\hline & R1 & 0,3 & 0,6 & 1 & & & 2 \\
\hline & & 3 & 7 & & & & \\
\hline & R2 & 0,3 & 0,6 & 1 & & & 2 \\
\hline & & 3 & 7 & & & & \\
\hline & R3 & 0,3 & 0,6 & 1 & & & 2 \\
\hline & & 3 & 7 & & & & \\
\hline & R4 & 0,3 & 0,6 & 1 & & & 2 \\
\hline & & 3 & 7 & & & & \\
\hline & R5 & 0,3 & 0,6 & 1 & & & 2 \\
\hline & & 3 & 7 & & & & \\
\hline & R6 & 0,3 & 0,6 & 1 & & & 2 \\
\hline & & 3 & 7 & & & & \\
\hline & R7 & 0,3 & 0,6 & 1 & & & 2 \\
\hline & & 3 & 7 & & & & \\
\hline @ุ & R8 & 0,3 & 0,6 & 1 & & & 2 \\
\hline$\overline{0}$ & & 3 & 7 & & & & \\
\hline 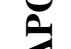 & R9 & 0,3 & 0,6 & 1 & & & 2 \\
\hline & & 3 & 7 & & & & \\
\hline & $\mathrm{R} 1$ & 0,3 & 0,6 & 1 & & & 2 \\
\hline & 0 & 3 & 7 & & & & \\
\hline & R1 & 0,3 & 0,6 & 1 & & & 2 \\
\hline & 1 & 3 & 7 & & & & \\
\hline & $\mathrm{R} 1$ & 0,3 & 0,6 & 1 & & & 2 \\
\hline & 2 & 3 & 7 & & & & \\
\hline & $\mathrm{R} 1$ & 0,3 & 0,6 & 1 & & & 2 \\
\hline & 3 & 3 & 7 & & & & \\
\hline & $\mathrm{R} 1$ & 0,3 & 0,6 & 1 & & & 2 \\
\hline & 4 & 3 & 7 & & & & \\
\hline & $\mathrm{R} 1$ & 0,3 & 0,6 & 1 & & & 2 \\
\hline & 5 & 3 & 7 & & & & \\
\hline & & & & & & & 2 \\
\hline
\end{tabular}

Tabel 10. Daftar Hasil Perhitungan Capability Level APO07.03 (Ketrampilan dan Kompetensi Staff)

\begin{tabular}{llllllll}
\hline P & R & L1 & L2 & L & L & L & C \\
& & & $\mathbf{3}$ & $\mathbf{4}$ & $\mathbf{5}$ & $\mathbf{L}$ \\
\hline \multirow{2}{*}{} & $\mathrm{R} 1$ & 0,3 & 0,6 & 1 & & & 2 \\
& 3 & 7 & & & & \\
\hline \multirow{2}{*}{$\mathrm{R} 2$} & 0,3 & 0,6 & 1 & & & 2 \\
& 3 & 7 & & & & \\
\hline
\end{tabular}


Available online at http://jurnal.goretanpena.com/index.php/JSSR

\begin{tabular}{lllll}
\hline \hline R3 & 0,3 & 0,6 & 1 & 2 \\
& 3 & 7 & & \\
\hline R4 & 0,3 & 0,6 & 1 & 2 \\
& 3 & 7 & & 2 \\
\hline R5 & 0,3 & 0,6 & 1 & \\
& 3 & 7 & & \\
\hline R6 & 0,3 & 0,6 & 1 & 2 \\
& 3 & 7 & & \\
\hline R7 & 0,3 & 0,6 & 1 & 2 \\
& 3 & 7 & & \\
\hline R8 & 0,3 & 0,6 & 1 & 2 \\
& 3 & 7 & & \\
\hline R9 & 0,3 & 0,6 & 1 & \\
& 3 & 7 & & \\
\hline R1 & 0,3 & 0,6 & 1 & \\
0 & 3 & 7 & & \\
\hline R1 & 0,3 & 0,6 & 1 & 2 \\
1 & 3 & 7 & & \\
\hline R1 & 0,3 & 0,6 & 1 & \\
2 & 3 & 7 & & \\
\hline R1 & 0,3 & 0,6 & 1 & \\
3 & 3 & 7 & & \\
\hline R1 & 0,3 & 0,6 & 1 & \\
4 & 3 & 7 & & \\
\hline R1 & 0,3 & 0,6 & 1 & \\
5 & 3 & 7 & & \\
& & & & 2 \\
\hline
\end{tabular}

Tabel 11. Daftar Hasil Perhitungan

Capability Level APO07.04 (Kinerja

Karyawan)

\begin{tabular}{|c|c|c|c|c|c|c|}
\hline $\mathbf{P}$ & $\mathbf{R}$ & L1 & L2 & L3 & $\begin{array}{ll}L & L \\
4 & 5\end{array}$ & CL \\
\hline \multirow{18}{*}{ 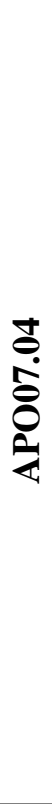 } & \multirow[t]{2}{*}{ R1 } & 0,3 & 0,7 & 0,8 & & 1,9 \\
\hline & & 6 & 3 & 2 & & 1 \\
\hline & \multirow[t]{2}{*}{ R2 } & 0,3 & 0,7 & 0,8 & & 1,9 \\
\hline & & 6 & 3 & 2 & & 1 \\
\hline & \multirow[t]{2}{*}{ R3 } & 0,3 & 0,7 & 0,8 & & 1,9 \\
\hline & & 6 & 3 & 2 & & 1 \\
\hline & \multirow[t]{2}{*}{$\mathrm{R} 4$} & 0,3 & 0,7 & 0,8 & & 1,9 \\
\hline & & 6 & 3 & 2 & & 1 \\
\hline & \multirow[t]{2}{*}{ R5 } & 0,3 & 0,7 & 0,8 & & 1,9 \\
\hline & & 6 & 3 & 2 & & 1 \\
\hline & \multirow[t]{2}{*}{ R6 } & 0,3 & 0,7 & 0,8 & & 1,9 \\
\hline & & 6 & 3 & 2 & & 1 \\
\hline & \multirow[t]{2}{*}{ R7 } & 0,3 & 0,7 & 0,8 & & 1,9 \\
\hline & & 6 & 3 & 2 & & 1 \\
\hline & \multirow[t]{2}{*}{ R8 } & 0,3 & 0,7 & 0,8 & & 1,9 \\
\hline & & 6 & 3 & 2 & & 1 \\
\hline & \multirow[t]{2}{*}{ R9 } & 0,3 & 0,7 & 0,8 & & 1,9 \\
\hline & & 6 & 3 & 2 & & 1 \\
\hline
\end{tabular}

\begin{tabular}{lllll} 
R1 & 0,3 & 0,7 & 0,8 & 1,9 \\
0 & 6 & 3 & 2 & 1 \\
\hline R1 & 0,3 & 0,7 & 0,8 & 1,9 \\
1 & 6 & 3 & 2 & 1 \\
\hline R1 & 0,3 & 0,7 & 0,8 & 1,9 \\
2 & 6 & 3 & 2 & 1 \\
R1 & 0,3 & 0,7 & 0,8 & 1,9 \\
3 & 6 & 3 & 2 & 1 \\
R1 & 0,3 & 0,7 & 0,8 & 1,9 \\
4 & 6 & 3 & 2 & 1 \\
R1 & 0,3 & 0,7 & 0,8 & 1,9 \\
5 & 6 & 3 & 2 & 1 \\
& & & & 1,9 \\
& & & & 1 \\
\hline
\end{tabular}

Tabel 12. Daftar Hasil Perhitungan Capability Level APO07.05

(Perencanaan, Pelacakan dan Tanggung Jawab I\&T)

\begin{tabular}{|c|c|c|c|c|c|c|}
\hline $\mathbf{P}$ & $\mathbf{R}$ & L1 & L2 & L3 & $\begin{array}{ll}L & L \\
4 & 5\end{array}$ & CL \\
\hline \multirow{30}{*}{$\begin{array}{l}\text { ô } \\
\hat{8} \\
\hat{8}\end{array}$} & \multirow{2}{*}{$\mathrm{R} 1$} & 0,2 & 0,8 & 0,8 & & 2,0 \\
\hline & & 9 & 6 & 6 & & 1 \\
\hline & \multirow[t]{2}{*}{$\mathrm{R} 2$} & 0,2 & 0,8 & 0,8 & & 2,0 \\
\hline & & 9 & 6 & 6 & & 1 \\
\hline & \multirow[t]{2}{*}{ R3 } & 0,2 & 0,8 & 0,8 & & 2,0 \\
\hline & & 9 & 6 & 6 & & 1 \\
\hline & \multirow[t]{2}{*}{$\mathrm{R} 4$} & 0,2 & 0,8 & 0,8 & & 2,0 \\
\hline & & 9 & 6 & 6 & & 1 \\
\hline & \multirow[t]{2}{*}{ R5 } & 0,2 & 0,8 & 0,8 & & 2,0 \\
\hline & & 9 & 6 & 6 & & 1 \\
\hline & \multirow{2}{*}{ R6 } & 0,2 & 0,8 & 0,8 & & 2,0 \\
\hline & & 9 & 6 & 6 & & 1 \\
\hline & \multirow[t]{2}{*}{$\mathrm{R} 7$} & 0,2 & 0,8 & 0,8 & & 2,0 \\
\hline & & 9 & 6 & 6 & & 1 \\
\hline & \multirow[t]{2}{*}{$\mathrm{R} 8$} & 0,2 & 0,8 & 0,8 & & 2,0 \\
\hline & & 9 & 6 & 6 & & 1 \\
\hline & \multirow[t]{2}{*}{ R9 } & 0,2 & 0,8 & 0,8 & & 2,0 \\
\hline & & 9 & 6 & 6 & & 1 \\
\hline & R1 & 0,2 & 0,8 & 0,8 & & 2,0 \\
\hline & 0 & 9 & 6 & 6 & & 1 \\
\hline & R1 & 0,2 & 0,8 & 0,8 & & 2,0 \\
\hline & 1 & 9 & 6 & 6 & & 1 \\
\hline & R1 & 0,2 & 0,8 & 0,8 & & 2,0 \\
\hline & 2 & 9 & 6 & 6 & & 1 \\
\hline & $\mathrm{R} 1$ & 0,2 & 0,8 & 0,8 & & 2,0 \\
\hline & 3 & 9 & 6 & 6 & & 1 \\
\hline & R1 & 0,2 & 0,8 & 0,8 & & 2,0 \\
\hline & 4 & 9 & 6 & 6 & & 1 \\
\hline & R1 & 0,2 & 0,8 & 0,8 & & 2,0 \\
\hline & 5 & 9 & 6 & 6 & & 1 \\
\hline
\end{tabular}


Available online at http://jurnal.goretanpena.com/index.php/JSSR

\begin{tabular}{|c|c|c|c|c|c|c|}
\hline & & & & & & $\begin{array}{l}2,0 \\
1\end{array}$ \\
\hline \multicolumn{7}{|c|}{$\begin{array}{c}\text { Tabel 13. Daftar Hasil Perhitungan } \\
\text { Capability Level APO07.06 (Pengelolaan } \\
\text { Staff) }\end{array}$} \\
\hline $\mathbf{P}$ & $\mathbf{R}$ & L1 & L2 & $\begin{array}{l}\mathbf{L} \\
\mathbf{3}\end{array}$ & $\begin{array}{ll}L & L \\
4 & 5\end{array}$ & $\begin{array}{l}\text { C } \\
\text { L }\end{array}$ \\
\hline \multirow{16}{*}{ 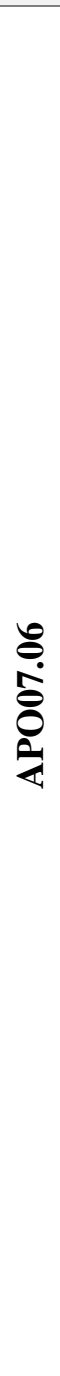 } & $\mathrm{R} 1$ & $\begin{array}{l}0,3 \\
3\end{array}$ & $\begin{array}{l}0,6 \\
7\end{array}$ & 1 & & 2 \\
\hline & $\mathrm{R} 2$ & $\begin{array}{l}0,3 \\
3\end{array}$ & $\begin{array}{l}0,6 \\
7 \\
\end{array}$ & 1 & & 2 \\
\hline & R3 & $\begin{array}{l}0,3 \\
3\end{array}$ & $\begin{array}{l}0,6 \\
7\end{array}$ & 1 & & 2 \\
\hline & R4 & $\begin{array}{l}0,3 \\
3\end{array}$ & $\begin{array}{l}0,6 \\
7\end{array}$ & 1 & & 2 \\
\hline & R5 & $\begin{array}{l}0,3 \\
3\end{array}$ & $\begin{array}{l}0,6 \\
7\end{array}$ & 1 & & 2 \\
\hline & R6 & $\begin{array}{l}0,3 \\
3\end{array}$ & $\begin{array}{l}0,6 \\
7\end{array}$ & 1 & & 2 \\
\hline & R7 & $\begin{array}{l}0,3 \\
3\end{array}$ & $\begin{array}{l}0,6 \\
7\end{array}$ & 1 & & 2 \\
\hline & R8 & $\begin{array}{l}0,3 \\
3\end{array}$ & $\begin{array}{l}0,6 \\
7\end{array}$ & 1 & & 2 \\
\hline & R9 & $\begin{array}{l}0,3 \\
3\end{array}$ & $\begin{array}{l}0,6 \\
7\end{array}$ & 1 & & 2 \\
\hline & $\begin{array}{l}\mathrm{R} 1 \\
0\end{array}$ & $\begin{array}{l}0,3 \\
3\end{array}$ & $\begin{array}{l}0,6 \\
7\end{array}$ & 1 & & 2 \\
\hline & & $\begin{array}{l}0,3 \\
3\end{array}$ & $\begin{array}{l}0,6 \\
7\end{array}$ & 1 & & 2 \\
\hline & $\begin{array}{l}\mathrm{R} 1 \\
2\end{array}$ & $\begin{array}{l}0,3 \\
3\end{array}$ & $\begin{array}{l}0,6 \\
7\end{array}$ & 1 & & 2 \\
\hline & $\begin{array}{l}\mathrm{R} 1 \\
3\end{array}$ & $\begin{array}{l}0,3 \\
3\end{array}$ & $\begin{array}{l}0,6 \\
7\end{array}$ & 1 & & 2 \\
\hline & R1 & 0,3 & 0,6 & 1 & & 2 \\
\hline & 4 & 3 & 7 & & & \\
\hline & $\begin{array}{l}\mathrm{R} 1 \\
5\end{array}$ & $\begin{array}{l}0,3 \\
3\end{array}$ & $\begin{array}{l}0,6 \\
7\end{array}$ & 1 & & 2 \\
\hline
\end{tabular}

Secara umum dari hasil perhitungan capability level pada domain APO07 (manage human resource) proses APO07.01, APO07.02, APO07.03, APO07.04, APO07.05 dan APO07.06 dapat disimpulkan bahwa :

1. Nilai capability level saat ini pada proses APO07.01 di Instidla cenderung pada level 2 Prosesnya tercapai tujuannya melalui penerapan seperangkat kegiatan

dasar, namun lengkap, yang dapat dicirikan sebagai dilaksanakan. Pada tingkat ini proses telah berjalan untuk mencapai tujuan prosesnya, hanya saja dalam pelaksanaanya masih berada ada proses yang belum berjalan.

2. Nilai capability level saat ini pada proses APO07.02 di Instidla cenderung pada level 2 Prosesnya tercapai tujuannya melalui penerapan seperangkat kegiatan dasar, namun lengkap, yang dapat dicirikan sebagai dilaksanakan. Pada tingkat ini proses telah berjalan untuk mencapai tujuan prosesnya, hanya saja dalam pelaksanaanya masih berada ada proses yang belum berjalan.

3. Nilai capability level saat ini pada proses APO07.03 di Instidla cenderung pada level 2 Prosesnya tercapai tujuannya melalui penerapan seperangkat kegiatan dasar, namun lengkap, yang dapat dicirikan sebagai dilaksanakan. Pada tingkat ini proses telah berjalan untuk mencapai tujuan prosesnya, hanya saja dalam pelaksanaanya masih berada ada proses yang belum berjalan.

4. Nilai capability level saat ini pada proses APO07.04 di Instidla cenderung pada level 1,91 Prosesnya kurang lebih mencapai tujuannya melalui penerapan serangkaian aktivitas yang tidak lengkap yang dapat dicirikan sebagai awal atau intuitif - tidak terlalu terorganisir. Pada tingkat ini proses telah berjalan untuk mencapai tujuan prosesnya, hanya saja dalam pelaksanaanya data yang tidak lengkap serta tidak teroganisir.

5. Nilai capability level saat ini pada proses APO07.05 di Instidla cenderung pada level 2,01 Prosesnya tercapai tujuannya melalui penerapan seperangkat kegiatan dasar, namun lengkap, yang dapat dicirikan sebagai dilaksanakan. Pada tingkat ini proses telah berjalan 
Available online at http://jurnal.goretanpena.com/index.php/JSSR

untuk mencapai tujuan prosesnya, hanya saja dalam pelaksanaanya masih berada ada proses yang belum berjalan.

6. Nilai capability level saat ini pada proses APO07.06 di Instidla cenderung pada level 2,00 Prosesnya tercapai tujuannya melalui penerapan seperangkat kegiatan dasar, namun lengkap, yang dapat dicirikan sebagai dilaksanakan. Pada tingkat ini proses telah berjalan untuk mencapai tujuan prosesnya, hanya saja dalam pelaksanaanya masih berada ada proses yang belum berjalan.

\section{Hasil Perhitungan Keseluruhan \\ Capabiity Level}

Pada hasil perhitungan di atas menunjukkan tentang perolehan nilai capablility level pada setiap proses domain. Berikut perolehan kemampuan Instidla dalam tata kelola teknologi saat ini secara umum : Kemampuan Instidla saat ini (current capability) dalam mengelola sumber daya manusia (APO07)

Tabel 14. Rekapitulasi Hasil Timgkat Kemampuan (Capability Level) Instidla Saat Ini

\begin{tabular}{lll}
\hline Domain & Proses & $\begin{array}{l}\text { Curent } \\
\text { Capability }\end{array}$ \\
\hline APO07 & Manage & 1,98 \\
& $\begin{array}{l}\text { Human } \\
\text { Resource }\end{array}$ \\
&
\end{tabular}

Rumus Perolehan untuk mendapat nilai kemampuan Instidla saat ini (current capability) dengan Domain APO07 (Manage Human Resource) adalah:

$$
\begin{aligned}
& C C=\frac{\sum C L_{2}}{\sum P_{0}} \\
& =\frac{C L_{A P 007,01+A P 0_{07,022}+A P O_{07,032}+A P 0_{07,04}+A P O_{0}}^{\sum P_{0}}}{6} \\
& =\frac{2,00+2,00+2,00+1,91+2,01+2}{6} \\
& =\frac{11,92}{6} \\
& =1,98
\end{aligned}
$$

Tabel 15. Hasil Temuan Capability Level APO07 (Manage Human Resource)

Proses Temuan Capability Leve

APO07.01 Adanya sumber daya TI pada Instidla

Adanya proses peninjauan terhadap sumber daya TI yang berada pada Instidla

APO07.02 Adanya proses identifikasi sumber daya TI yang bekerja sesuai dengan kompetensi yang dimiliki

Belum adanya standarisasi terkait bidang pada Instidla dengan kompetensi yang dimiliki sumber daya TI

APO07.03 Adanya proses idnetifikasi kemampuan kompetensi dan keterampilan pegawai

Adanya proses keikutsertaan pegawai dalam pelatiham untuk peningkatan keterampilan dan kompetensi yang dimiliki Adanya proses perubahan terkait kemajuan teknologi informasi

Belum adanya standarisasi dalam menentuka kompetensi dan keterampilan yang dibutuhkan saat ini

APO07.04 Adanya proses evaluasi kinerja pegawai Instidal Adanya program kerja tahunan

Adanya jadwal program kerja

Adanya proses reward dan punishment pada Instidla

APO07.05 Adanya proses dalam perencanaan, pelacakan dan tanggung jawab I\&T

Adanya proses identifikasi dalam penetapan serta perubahan kontrak staff untuk pegawai di Instidla

Define Road Map

Berikut gambaran APO07 pada tingkat kemampuan saat ini (current capability) 
Available online at http://jurnal.goretanpena.com/index.php/JSSR

dan kemmpuan yang diharapkan (target capability)

Tabel 15. Tingkat Kemampuan saat ini

\begin{tabular}{llll}
\hline $\begin{array}{l}\text { Domai } \\
\text { n }\end{array}$ & Proses & $\begin{array}{l}\text { Current } \\
\text { Capabili } \\
\text { ty }\end{array}$ & $\begin{array}{l}\text { Expecte } \\
\text { d } \\
\text { Capabili } \\
\text { ty }\end{array}$ \\
\hline APO0 & $\begin{array}{l}\text { Manage } \\
\text { H } 1,98\end{array}$ & 3 \\
& $\begin{array}{l}\text { Human } \\
\text { Resour } \\
\text { ce }\end{array}$ & & \\
& & \\
\hline
\end{tabular}

\section{Analisa Gap pada Manage Human Resource}

Tabel 16. Gap Capability Level Proses APO07.01

\begin{tabular}{llr}
\hline Proses & \multicolumn{2}{l}{ Gap Capability Level } \\
\hline APO07.01 & Belum & adanya \\
& standarisasi & terkait \\
& kebutuhan sumber daya \\
& TI pada Instidla & \\
& Belum & adanya \\
& pendefinisian terkait \\
& kebutuhan karyawan / \\
& staff pada instidla \\
\hline
\end{tabular}

Tabel 17. Gap Capability Level Proses APO07.02

\begin{tabular}{|c|c|}
\hline \multirow{7}{*}{$\begin{array}{l}\text { Proses } \\
\text { APO07.02 }\end{array}$} & Gap Capability Level \\
\hline & Belum adanya standarisasi \\
\hline & bidang \\
\hline & Instidla \\
\hline & $\begin{array}{l}\text { kompetensi yang dimiliki } \\
\text { sumber daya TI }\end{array}$ \\
\hline & $\begin{array}{l}\text { Belum adanya identifikasi } \\
\text { pada kemampuan yang }\end{array}$ \\
\hline & staff Instidla \\
\hline
\end{tabular}

Tabel 18. Gap Capability Level Proses

\begin{tabular}{llr} 
& \multicolumn{3}{l}{ APO07.03 } & \\
\hline Proses & \multicolumn{2}{l}{ Gap Capability Level } \\
\hline APO07.03 & Belum & adanya \\
& standarisasi & terkait \\
& keterampilan & dan \\
& kompetensi & yang \\
& dimiliki yang & sudah \\
& dilakukan dan tercapai. \\
& Belum adanya & rencana \\
& yang akan & dicapai \\
\hline
\end{tabular}

terkait pengembangan

keterampilan dan kompetensi yang dimiliki karyawan / staff pada Instidla

Tabel 19. Gap Capability Level Proses APO07.04

\begin{tabular}{|c|c|}
\hline Proses & Gap Capability Level \\
\hline APO07.04 & $\begin{array}{l}\text { Belum adanya } \\
\text { standarisasi terkait } \\
\text { kinerja karyawan } \\
\text { Belum adanya proses } \\
\text { evaluasi kinerja terhadap } \\
\text { karyawana / staff oleh } \\
\text { atasan bagian }\end{array}$ \\
\hline
\end{tabular}

Tabel 20. Gap Capability Level Proses APO07.05

\begin{tabular}{llr}
\hline Proses & \multicolumn{2}{c}{ Gap Capability Level } \\
\hline APO07.05 & Belum adanya standarisasi \\
& terkait perencanaan, \\
& pelacakan dan tanggung \\
& jawab I\&T pada Instidla \\
& Belum adanya evaluasi \\
& terhadap & proses \\
& perencanaan, pelacakan \\
& oleh Instidla \\
\hline
\end{tabular}

Tabel 21. Gap Capability Level Proses APO07.06

\begin{tabular}{|c|c|}
\hline Proses & Gap Capability Level \\
\hline APO07.06 & $\begin{array}{l}\text { Belum adanya standarisasi } \\
\text { terkait penetapan kontrak } \\
\text { karyawan pada instidla } \\
\text { Belum adanya identifikasi } \\
\text { kontrak secara berkala saat } \\
\text { ini dan perubahan pada } \\
\text { kontrak staff }\end{array}$ \\
\hline
\end{tabular}

\section{Rekomendasi}

1. Pada proses APO07 terdapat 6 rekomendasi perbaikan yang diberikan, yakni :

2. Membuat skema kebutuhan karyawan yang dibutuhkan pada perguruan tinggi Instidla

3. Membuat dan menyesuaikan kebutuhan personal sumber daya 
Available online at http://jurnal.goretanpena.com/index.php/JSSR

dengan uraian tugas yang dikerjakan pada perguruan tinggi Instidla.

4. Membuat skema terkait pelatihan kompetensi terhadap seluruh personal sumber daya pada perguruan tinggi Instidla.

5. Melakukan evaluasi, pendokumentasian dan pelaporan terhadap uraian tugas yang dikerjakan oleh sumber daya / personal pada setiap personal di unit perguruan tinggi Instidla

6. Melakukan skema terkait uraian tugas yang dikerjakan, pendokumentasian serta pelaporan dan evaluasi terhadap uraian tugas yang dilaksanakan pada unit perguruan tinggi Instidla

7. Melakukan peninjauan ulang dan menskema ulang perjanjian dari kebutuhan, pengembangan serta kinerja bagi sumber daya kontrak pada perguruan tinggi Instidla

\section{SIMPULAN}

Berdasarkan hasil penelitian terkait tata kelola teknologi informasi yang sudah dilakukan pada Peguruan Tinggi Instidla menggunakan framework cobit 2019 pada proses APO07, maka dapat disimpulkan :

Hasil kuisioner dan wawancara tingkat kapabilitas pada level 1, Tingkat kapabilitas yang diperoleh serta target level yang diharapkan, maka dapat disimpulkan bahwa gap analisis pada proses APO07 berada pada level 1 yang berarti Perguruan Tinggi Instidla Prosesnya kurang lebih mencapai tujuan melalui penerapan serangkaian aktivitas yang tidak lengkap atau tidak terlalu terorganisir. Sedangkan pada level 3 Prosesnya tercapai tujuannya dengan cara yang jauh lebih terorganisir dengan menggunakan aset organisasi. Proses biasanya didefinisikan dengan baik Hasil gap analisis pada proses ini sebesar 2 .

Dari hasil analisis tingkat kapabilitas dan analisis gap pada proses APO07, maka rekomendasi perbaikan yang diusulkan adalah :
1. Membuat skema kebutuhan karyawan yang dibutuhkan pada perguruan tinggi Instidla

2. Membuat dan menyesuaikan kebutuhan personal sumber daya dengan uraian tugas yang dikerjakan pada perguruan tinggi Instidla.

3. Membuat skema terkait pelatihan kompetensi terhadap seluruh personal sumber daya pada perguruan tinggi Instidla.

4. Melakukan evaluasi, pendokumentasian dan pelaporan terhadap uraian tugas yang dikerjakan oleh sumber daya / personal pada setiap personal di unit perguruan tinggi Instidla

5. Melakukan skema terkait uraian tugas yang dikerjakan, pendokumentasian serta pelaporan dan evaluasi terhadap uraian tugas yang dilaksanakan pada unit perguruan tinggi Instidla

6. Melakukan peninjauan ulang dan menskema ulang perjanjian dari kebutuhan, pengembangan serta kinerja bagi sumber daya kontrak pada perguruan tinggi Instidla

\section{DAFTAR PUSTAKA}

Abdulrasool, Fatema Ebrahim, and Stephen J. Turnbull. 2020. 'Exploring Security, Risk, and Compliance Driven IT Governance Model for Universities: Applied Research Based on the COBIT Framework'. International Journal of Electronic Banking 2(3):237. doi: 10.1504/IJEBANK.2020.111438.

Evangelista, Alessandro, Lorenzo Ardito, Antonio Boccaccio, Michele Fiorentino, Antonio Messeni Petruzzelli, and Antonio E. Uva. 2020. 'Unveiling the Technological Trends of Augmented Reality: A Patent Analysis'. Computers in Industry 118.

Fantini, Paola, Marta Pinzone, and Marco Taisch. 2020. 'Placing the Operator at the Centre of Industry 4.0 Design: 
Available online at http://jurnal.goretanpena.com/index.php/JSSR

Modelling and Assessing Human Activities within Cyber-Physical Systems'. Computers and Industrial Engineering $139 . \quad$ doi: 10.1016/j.cie.2018.01.025

Gunadi, Faustina, and Septian Rheno Widianto. 2020. 'Efektifitas Pelaporan Pajak Online Di Indonesia Berbasis Cobit 5.0 Pada Domain MEA (Monitor, Evaluate, Assess)'. Seminar Nasional Teknologi Komputer \& Sains (SAINTEKS) 1(1):82-85.

De Haes, Steven, Wim Van Grembergen, and Roger S. Debreceny. 2013. 'COBIT 5 and Enterprise Governance of Information Technology: Building Blocks and Research Opportunities'. Journal of Information Systems 27(1):307-24. doi: 10.2308/ISYS-50422.

De Haes, Steven, Wim Van Grembergen, Anant Joshi, and Tim Huygh. 2020. 'COBIT as a Framework for Enterprise Governance of IT'. 12562. doi: 10.1007/978-3-030-259181_5.

Haouam, Djemaa. 2020. 'IT Governance Impact on Financial Reporting Quality Using COBIT Framework'. Global Journal of Computer Sciences: Theory and Research
10(1):1-10.

doi: 10.18844/GJCS.V10I1.4143.

Majumdar, Abhijit, Himanshu Garg, and Rohan Jain. 2021. 'Managing the Barriers of Industry 4.0 Adoption and Implementation in Textile and Clothing Industry: Interpretive Structural Model and Triple Helix Framework'. Computers in Industry 125. doi: 10.1016/j.compind.2020.103372.

Nachrowi, Erika, Yani Nurhadryani, and Heru Sukoco. 2020. 'Evaluation of Governance and Management of Information Technology Services Using Cobit 2019 and ITIL 4'. Jurnal RESTI (Rekayasa Sistem Dan Teknologi Informasi) 4(4):764-74. doi: 10.29207/RESTI.V4I4.2265.

Syuhada, Aldy Maulana. 2021. 'Kajian Perbandingan Cobit 5 Dengan Cobit 2019 Sebagai Framework Audit Tata Kelola Teknologi Informasi'. Syntax Literate; Jurnal Ilmiah Indonesia 6(1):30-39. doi: 10.36418/SYNTAXLITERATE.V6I1.2082. 